\title{
Koperasi Dan Baitul Maal Wattamwil (BMT) Dalam Pandangan Islam (Analisis Keabsahan Bentuk Badan Usaha Menurut Syariat Islam)
}

\author{
Munawwaroh ${ }^{1}$ \\ Fakultas Ekonomi dan Bisnis Islam Institut Agama Islam (IAI) Yasni Bungo \\ E-mail : mumunalkautsar@gmail.com \\ Rahmawati ${ }^{2}$ \\ Fakultas Ekonomi dan Bisnis Islam Institut Agama Islam (IAI) Yasni Bungo \\ E-mail : mumunalkautsar@gmail.com
}

\begin{abstract}
Cooperative and Baitul maal wattamwil are one of the existing and developing business entities in indonesia. Islam has also outlined legal laws related to the formation of business entities, in the study of fiqh muamalah it is known as syirkah. This study aims to describe how the law of cooverative business entities and Baitul maal wattamwil when viewed from islamic law, especially laws related to syirkah. The method used in this research is literature review. The results of this study explain that cooperative business entities and Baitul maal wattamwil are not in accordance with islamic law or do not meet the provisions related to syirkah law in islam.
\end{abstract}

Keywords: Cooperative, Baitul Maal Wattamwil , Business Entity, Islamic Law

\begin{abstract}
Abstrak
Koperasi dan baitul maal wattamwil (BMT) merupakan salah satu bentuk badan usaha yang ada dan berkembang di Indonesia. Islam juga telah menggariskan hukum-hukum yang terkait dengan pembentukan badan usaha, dalam kajian fiqh muamalah dikenal dengan istilah syirkah. Penelitian ini bertujuan untuk memaparkan bagaimana hukum badan usaha koperasi dan baitul maal wattamwil jika ditinjau dari syariat Islam, khususnya hukum-hukum yang berkaitan dengan syirkah. Metode yang digunakan dalam penelitian ini adalah telaah pustaka. Hasil penelitian ini menjelaskan bahwa badan usaha koperasi dan baitul maal wattamwil tidak sesuai dengan syariat Islam atau tidak memenuhi ketentuan-ketentuan yang terkait dengan hukum syirkah di dalam Islam.
\end{abstract}

Kata kunci : Koperasi, Baitul Maal Wattamwil, Badan Usaha, Syariat Islam

\section{A. Pendahuluan}

Koperasi dan Baitul Maal Wattamwil atau lebih dikenal dengan BMT sudah tidak asing lagi di Indonesia. Gerakan koperasi di Indonesia diprakarsai oleh seorang pamong praja (pegawai negeri di masa penjajahan Belanda) bernama Raden Bei Aria Wiraatmadja yang mendirikan lembaga De Poerwokertosche Hulp en Spararbank der Inlandsche Hoofden atau Bank Bantuan dan Simpanan Milik Kaum Priyayi Purwokereto", suatu lembaga keuangan yang melayani orang-orang berkebangsaan

\footnotetext{
${ }^{1}$ Dosen Fakultas Ekonomi dan Bisnis Islam Institut Agama Islam (IAI) Yasni Bungo

2 Dosen Fakultas Ekonomi dan Bisnis Islam Institut Agama Islam (IAI) Yasni Bungo
} 
Indonesia (pribumi) pada tanggal 16 Desember 1895. ${ }^{3}$ Sedangkan BMT atau sering di kenal juga sebagai koperasi syariah baru berdiri hampir satu abad setelah berdirinya koperasi di purwokerto. Baitut Maal Wattamwil yang pertama kali berdiri adalah Baitul Maal wattamwil (BMT) Bina Insan Kamil pada tahun 1992.

Undang-undang No.25 tahun 1992 tentang Perkoperasian merupakan payung hukum dari aktivitas koperasi di Indonesia. Menurut pasal 1 Undang-undang tersebut, Koperasi adalah badan usaha yang beranggotakan orang-seorang atau badan hukum koperasi dengan melandaskan kegiatannya berdasarkan prinsip koperasi sekaligus sebagai gerakan ekonomi rakyat yang berdasar atas asas kekeluargaan. ${ }^{4}$ Sedangkan landasan operasional dari Baitul Maal Wattamwil atau yang hari ini telah di ganti namanya menjadi Koperasi Simpan Pinjam Pembiayaan Syariah (KSPPS) adalah Peraturan Menteri Koperasi dan Usaha Kecil dan Menengah RI Nomor 11/PER/M.KUKM/XII/2017 Tentang Pelaksanaan Kegiatan Usaha Simpan Pinjam dan Pembiayaan Syariah Oleh Koperasi. Menurut Peraturan Menteri ini, Koperasi Simpan Pinjam dan Pembiayaan Syariah selanjutnya disingkat KSPPS adalah koperasi yang kegiatan usaha simpan, pinjam dan pembiayaan sesuai prinsip syariah, termasuk mengelola zakat, infak, sedekah dan wakaf. ${ }^{5}$

Dalam Islam sendiri, pembahasan tentang koperasi atau Koperasi Simpan Pinjam Pembiayaan Syariah (KSPPS) telah banyak di bahas oleh para ulama di dalam kitabkitab mereka. Salah satu yang paling fenomenal adalah kitab yang ditulis oleh AlAllamah Al-Qadhi syaikh Taqiyuddin An-Nabhani yang berjudul An-Nizham AlIqtishadi fi al-Islam. Di dalam bukunya beliau menjelaskan bahwa koperasi adalah salah satu jenis perseroan kapitalis. Koperasi tetap merupakan bentuk perseroan meskipun namanya adalah koperasi. Koperasi Adalah bentuk penanaman saham di antara sekelompok orang yang melakukan kesepakatan antarsesama mereka untuk mengadakan kerjasama (perseroan) sesuai dengan kondisi tertentu mereka. ${ }^{6}$

\footnotetext{
${ }^{3}$ Nur S.Buchori et,al.Manajemen Koperasi Syariah:teori dan Praktik.h.1

${ }^{4}$ Undang-Undang RI No.25 tahun 1992 Tentang Perkoperasian. Lembaran Negara RI Tahun 1992 Nomor 116

5 Peraturan Menteri Koperasi dan Usaha Kecil dan Menengah RI Nomor 11/PER/M/KUKM/XII/2017 Tentang PelaksanaanKegiatan Usaha Simpan Pinjam dan Pembiayaan Syariah oleh Koperasi Bab I Bagian Umum poin ke-2

${ }^{6}$ Taqiyuddin An-Nabhani,An-Nizham al-Iqtishadi fi al-Islam, terj,Redaksi al-Azhar Press,Sistim Ekonomi Islam,h.186
} 
Jika kita meneliti lebih dalam terkait bentuk badan usaha koperasi atau Baitul Maal Wattamwil (BMT) dalam kitab-kitab ulama, maka pembahasan tentang bentuk badan usaha koperasi ini tidak bisa kita lepaskan dari model Syirkah di dalam Islam. Syirkah atau perseroan merupakan bentuk kerjasama antara dua pihak untuk melakukan aktivitas tertentu, bisa dalam bentuk kerjasama dalam kepemilikan terhadap suatu harta yang biasa di kenal dengan istilah syirkah al-amlak (kerjasama dalam kepemilikan harta), bisa juga dalam bentuk kerjasama dalam melakukan aktivitas bisnis tertentu (tasharruf maaliyah) yang biasa di kenal dengan istilah syirkah al-uqud (kerjasama dalam aktivitas bisnis).

Dalam Islam kita mengenal ada beberapa bentuk atau model dalam kerjasama/perseroan (syirkah) dalam aktivitas bisnis (syirkah al-uqud), yakni Syirkah inan, syirkah abdan, syirkah mudharabah, syirkah wujuh dan syirkah mufawadhah. Koperasi ataubaitul maal wattamwil (BMT) dalam pembentukan badan usahanya selain harus mengikuti perundang-undangan yang berlaku di Indonesia tentu juga harus mengikuti salah satu bentuk atau model syirkah yang ada di dalam Islam agar pembentukan badan usahanya di anggap sah menurut syariat Islam sehingga sah pula dalam melakukan aktivitas usahanya.

\section{B. Landasan Teori}

\section{Koperasi}

\section{a. Pengertian Koperasi}

Koperasi adalah badan usaha yang beranggotakan orang-seorang atau badan hukum koperasi dengan melandaskan kegiatannya berdasarkan prinsip koperasi sekaligus sebagai gerakan ekonomi rakyat yang berdasar atas asas kekeluargaan. ${ }^{7}$

b. Prinsip-prinsip koperasi

Koperasi melaksanakan prinsip koperasi sebagai berikut :8

1) keanggotaan bersifat sukarela dan terbuka

2) pengelolaan dilakukan secara demokratis

3) pembagian sisa hasil usaha dilakukan secara adil sebanding dengan besarnya jasa usaha masing-masing anggota

7 Undang-Undang RI No.25 tahun 1992 Tentang Perkoperasian. Lembaran Negara RI Tahun 1992 Nomor 116

${ }^{8}$ Ibid 
4) pemberian jasa terbatas terhadap modal

5) kemandirian

c. struktur organisasi

Perangkat organisasi koperasi terdiri dari : ${ }^{9}$

1) Rapat anggota

a) Rapat anggota merupakan pemegang kekuasaan tertinggi dalam koperasi

b) Rapat anggota dihadiri oleh anggota yang pelaksanaannya diatur dalam anggaran dasar

c) Rapat anggota menetapkan :

1. Anggaran dasar

2. Kebijaksanaan umum di bidang organisasi, manajemen, dan usaha koperasi

3. Pemilihan, pengangkatan, pemberhentian pengurus dan pengawas

4. Rencana kerja, rencana anggaran pendapatan dan belanja koperasi, serta pengesahan laporan keuangan

5. Pengesahan pertanggungjawaban pengurus dalam pelaksanaan tugasnya

6. Pembagian sisa hasil usaha

7. Penggabungan, peleburan, pembagian, dan pembubaran koperasi

d) Keputusan rapat anggota diambil berdasarkan musyawarah untuk mencapai mufakat

e) Apabila tidak diperoleh keputusan dengan cara musyawarah, maka pengambilan keputusan dilakukan berdasarkan suara terbanyak

f) Dalam hal pemungutan suara, setiap anggota mempunyai hak satu suara

g) Hak suara dalam koperasi sekunder dapat diatur dalam anggaran dasar dengan mempertimbangkan jumlah anggota dan jasa usaha koperasi-anggota secara berimbang 
Munawwaroh, Rahmawati : Koperasi Dan Baitul Maal...

h) Rapat anggota berhak meminta keterangan dan pertanggungjawaban pengurus dan pengawas mengenai pengelolaan koperasi

i) Rapat anggota dilakukan paling sedikit sekali dalam satu tahun

j) Rapat anggota untuk mengesahkan pertanggungjawaban pengurus diselenggarakan paling lambat enam bulan setelah tahun buku lampau

k) Selain rapat anggota sebagaimana dimaksud dalam pasal 26, koperasi dapat melakukan rapat anggota luar biasa apabila keadaan mengharuskan adanya keputusan segera yang wewenangnya ada pada rapat anggota

l) Rapat anggota luar biasa dapat diadakan atas permintaan sejumlah anggota koperasi dan atau keputusan pengurus yang pelaksanaanya diatur dalam anggaran dasar

m) Rapat anggota luar biasa mempunyai wewenang yang sama dengan rapat anggota luar biasa diatur dalam anggaran dasar

2) Pengurus

a) Pengurus dipilih dari dan oleh anggota koperasi dalam rapat anggota

b) Pengurus merupakan pemegang kuasa rapat anggota

c) Untuk pertama kali, susunan dan nama anggota pengurus dicantumkan dalam kata pendirian

d) Masa jabatan pengurus paling lama lima tahun

e) Persyaratan untuk dapat dipilih dan diangkat menjadi anggota pengurus ditetapkan dalam anggaran dasar

f) Pengurus bertugas :

1. Mengelola koperasi dan usahanya

2. Mengajukan rencana-rencana kerja serta rancangan rencana anggaran pendapatan dan belanja koperasi

3. Menyelenggarakan rapat anggota

4. Mengajukan laporan keuangan dan pertangungjawaban pelaksanaan tugas 
Munawwaroh, Rahmawati : Koperasi Dan Baitul Maal...

5. Menyelenggarakan pembukuan keuangan dan inventaris secara tertib

6. Memelihara daftar buku anggota dan pengurus

g) Pengurus berwenang :

1. Mewakili koperasi didalam dan diluar pengadilan

2. Memutusakan penerimaan dan penolakan anggota baru serta pemberhentian anggota sesuai dengan ketentuan dalam anggaran dasar

3. Melakukan tindakan dan upaya bagi kepentingan dan kemanfaatan koperasi sesuai dengan tanggungjawabnya dan keputusan rapat anggota

h) Pengurus bertanggungjawab mengenai segala kegiatan pengelolaan koperasi dan usahanya kepada rapat anggota atau rapat anggota luar biasa

i) Pengurus koperasi dapat mengangkat pengelola yang diberi wewenang dan kuasa untuk mengelola usaha

j) Dalam hal pengurus koperasi bermaksud untuk mengangkat pengelola, maka rencana pengangkatan tersebut diajukan kepada rapat anggota untuk mendapat persetujuan

k) Pengelola bertanggungjawab kepada pengurus

l) Pengelolaan usaha oleh pengelola tidak mengurangi tanggungjawab pengurus

m) Hubungan antara pengelola usaha dengan pengurus koperasi merupakan hubungan kerja atas dasar perikatan

n) Pengurus, baik bersama-sama maupun sendiri-sendiri menanggung kerugian yang diderita koperasi, karena tindakan yang dilakukan karena kesengajaan atau kelalaiannya

o) Disamping penggantian kerugian tersebut apabila tindakan itu dilakukan dengan kesengajaan, tidak menutup kemungkinan bagi penuntut hukum untuk melakukan penuntutan

p) Setelah tahun buku koperasi ditutup paling lambat satu bulan sebelum diselenggarakan rapat anggota tahunan,pengurus menyusun laporan tahunan yang memuat sekurang-kurangnya: 
1. Perhitungan tahunan yang terdiri dari neraca akhir tahun buku yang baru lampau dan perhitungan hasil usaha dari tahun yang bersangkutan serta penjelasan atas dokumen tersebut

2. Keadaan dan usaha koperasi serta hasil usaha yang dapat dicapai

q) Laporan tahunan ditandatangani oleh semua anggota pengurus

r) Apabila salah seorang anggota pengurus tdak menandatangani laporan tahunan tersebut, anggota yang bersangkuitan menjelaskan secara tertulis

s) Persetujuan terhadap laporan tahunan, termasuk pengesahan perhitungan tahunan merupakan penerimaan pertanggungjawaban pengurus oleh rapat anggota

3) Pengawas

a) Pengawas dipilih dari dan oleh anggota koperasi dalam rapat anggota

b) Pengawas bertanggungjawab kepada rapat anggota

c) Persyaratan untuk dapat dipilih dan diangkat sebagi anggota pengawas ditetapkan dalam anggaran dasar

d) Pengawas bertugas:

1) Melakukan pengawasan terhadap pelaksanaan kebijaksanaan dan pengelolaan koperasi

2) Membuat laporan tertulis tentang hasil pengawasannya

e) Pengawas berwenang:

1) Meneliti catatan yang ada pada koperasi

2) Mendapatkan segala keterangan yang diperlukan

f) Pengawas harus merahasiakan hasil pengawasanya terhadap pihak ketiga

g) Koperasi dapat meminta jasa audit kepada akuntan publik

h) Modal koperasi terdiri dari modal sendiri dan modal pinjaman

i) Modal sendiri dapat berasal dari; simpanan pokok, simpanan wajib, dana cadangan, hibah 
j) Modal pinjaman dapat berasal dari; anggota, koperasi lainnya dan atau anggotanya, bank dan lembaga, penerbitan obligasi dan surat hutang lainnya, sumber lain yang sah

k) Selain modal koperasi dapat pula melakukan pemupukan modal yang berasal dari modal penyertaan

l) Ketentuan mengenai pemupukan modal yang berasal dari modal penyertaan diatur lebih lanjut dengan peraturan pemerintah

\section{Baitul Maal Wattamwil (BMT)}

\section{a. Pengertian}

Baitul maal wattamwil adalah lembaga keuangan dengan konsep syariah yang lahir sebagai pilihan yang menggabungkan konsep maal dan tamwil dalam satu kegiatan lembaga. Konsep maal lahir dan menjadi bagian dari kehidupan masyarakat muslim dalam hal menghimpun dan menyelurkan dana untuk zakat, infak, dan shadaqah (ZIS) secara produktif. Sedangkan konsep tamwil lahir untuk kegiatan bisnis produktif yang murni untuk mendapatkan keuntungan dengan sektor masyarakat menengah ke bawah (mikro). ${ }^{10}$

Baitul maal wattamwil dalam operasional dan badan hukumnya saat ini menggunakan bentuk badan hukum koperasi. Sehingga dalam aturan operasionalnya merujuk kepada aturan- aturan yang berlaku bagi koperasi pada umumnya. Dalam perkembangannya baitul maal wattamwil telah di akomodir dan dijelaskan lebih detil tentang mekanisme operasionalnya berdasarkan Peraturan Menteri Koperasi dan Usaha Kecil dan Menengah RI Nomor: 11/PER/M.UKM/XII/2017 Tentang Pelaksanaan Kegiatan Usaha Simpan Pinjam dan Pembiayaan Syariah oleh Koperasi. Jika kita perhatikan secara mendalam terkait operasional dan produk-produk baitul maal wattamwil (BMT), berfokus pada dua hal yakni maal (zakat, infak, shadaqah) dan tamwil (Bisnis). Maka dalam Peraturan Menteri ini, telah dijelaskan secara jelas dan detil, sehingga baitul maal wattamwil bisa di katakan berbentuk Koperasi Simpan Pinjam Pembiayaan Syariah (KSPPS), karena KSPPS dalam operasionalnya selain fokus pada bisnis yang berdasarkan syariah juga diperbolehkan untuk mengelola dana zakat, infak dan shadaqah (ZIS).

${ }^{10}$ Novita Dewi Masyithoh, " Analisis Normatif Undang-Undang No.1 Tahun 2013 Tentang Lembaga Keuangan Mikro (LKM) Atas Status Badan Hukumj dan Pengawasan Baitul Maal Wattamwil (BMT)", Dalam Economica, Volume V, Edisi 2, h.17 


\section{b. Ketentuan-ketentuan terkait Baitul Maal Wattamwil (BMT/KSPPS) ${ }^{11}$}

1) Prinsip Syariah adalah prinsip hukum Islam dalam kegiatan usaha koperasi berdasarkan fatwa yang dikeluarkan oleh Dewan syariah Nasional Majelis Ulama Indonesia.

2) Pengurus adalah anggota koperasi yang diangkat dan dipilih dalam rapat anggota untuk mengurus organisasi dan usaha koperasi.

3) Pengelola adalah anggota koperasi dan/atau pihak ketiga yang diangkat oleh pengurus dan diberi wewenang untuk mengelola usaha simpan pinjam dan pembiayaan syariah.

4) Anggota koperasi yang selanjutnya disebut anggota adalah pemilik sekaligus pengguna jasa koperasi dan tercatat dalam buku daftar anggota.

5) Calon anggota adalah orang perorangan/koperasi yang telah melunasi pembayaran simpanan pokok kepada koperasinya, tetapi secara formal belum sepenuhnya melengkapi persyaratan admisnistratif, antara lain belum menandatangani buku daftar anggota.

6) Simpanan adalah dana yang dipercayakan oleh anggota, calon anggota, koperasi lain, dan/atau anggotanya kepada koperasi pada saat masuk menjadi anggota, yang tidak dapat diambil kembali selama yang bersangkutan masih menjadi anggota.

7) Pinjaman adalah penyedian uang atau tagihan yang berdasarkan persetujuan atau kesepakatan pinjam meminjam antara koperasi dengan pihak lain yang mewajibkan pihak peminjam untuk melunasi hutangnya setelah jangka waktu tertentu tanpa imbalan.

8) Pembiayaan adalah penyedian dana atau tagihan yang dipersamakan dengan itu berupa :

a) Transaksi bagi hasil dalam bentuk mudharabah dan musyarakah;

b) Transaksi sewa-menyewa yang diakhiri dengan perpindahan kepemilikan dalam bentuk ijarah muntahiya bit tamlik, sewamenyewa atas manfaat suatu barang dan/atau jasa dalam bentuk

11 Peraturan Menteri Koperasi dan Usaha Kecil dan Menengah RI Nomor 11/PER/M/KUKM/XII/2017 Tentang Pelaksanaan Kegiatan Usaha Simpan Pinjam dan Pembiayaan Syariah oleh Koperasi Bab I Bagian Umum 
ijarah maushufah fi zimmah dan sewa-menyewa atas manfaat dari transaksi multi jasa dalam bentuk ijarah dan kafalah;

c) Transaksi jual beli dalam bentuk piutang murabahah, salam, Istishna;, dan musyarakah mutanaqishah;

d) Transaksi pinjam meminjam dalam bentuk piutang qordh atau dengan pemeliharaan jaminan dalam bentuk rahn.

\section{c. Badan Usaha Koperasi Menurut Islam}

\section{Badan Usaha Koperasi}

Badan usaha adalah suatu kesatuan organisasi dan ekonomis berbadan hukum yang menggunakan modal dan tenaga kerja untuk memperoleh laba atau keuntungan dan memberikan layanan kepada masyarakat. Jadi di dalam sebuah badan usaha harus ada syarat-syarat administrative dan bersifat resmi, serta diresmikan oleh pejabat yang berwenang. ${ }^{12}$

Koperasi adalah salah satu jenis perseroan kapitalis. Koperasi tetap merupakan bentuk perseroan meskipun namanya adalah koperasi. Koperasi adalah bentuk penanaman saham di antara sekelompok orang yang melakukan kesepakatan antara sesame mereka untuk mengadakan kerjasama (perseroan) sesuai kondisi tertentu mereka. ${ }^{13}$

Koperasi dalam model perdagangan umum biasanya didirikan dengan tujuan untuk membantu para anggotanya, atau menjamin kepentingankepentingan ekonomi mereka yang serba terbatas. Koperasi biasanya merekrut juristicpersonality untuk melakukan perseroan. Karena itu, koperasi berbeda dengan organisasi-organisasi lain karena pada dasarnya organisasi-organisasi selain koperasi terlepas dari tujuan-tujuan ekonomi. ${ }^{14}$

\section{Koperasi Menurut Islam}

Koperasi baik yang konvensional maupun yang syariah atau BMT atau yang dijelaskan oleh Peraturan Menteri Koperasi dan UKM Nomor 11 tahun 2017 sebagai Koperasi Simpan Pinjam Pembiayaan Syariah (KSPPS) merupakan

\footnotetext{
12 Dwi Utami Nuraini, Badan Usaha dan Koperasi Dalam Perekonomian Indonesia,h.23

13 Taqiyuddin An-Nabhani,An-Nizham al-Iqtishadi fi al-Islam, terj,Redaksi al-Azhar Press,Sistim Ekonomi Islam,h.186

${ }^{14}$ Taqiyuddin An-Nabhani,An-Nizham al-Iqtishadi fi al-Islam, terj,Redaksi al-Azhar Press,Sistim Ekonomi Islam,h.186
} 
suatu bentuk badan usaha. Dalam istilah fikih muamalah di kenal dengan istilah syirkah. Maka jika kita ingin mengetahui atau menganalisis koperasi, kita harus terlebih dahulu memahami hukum-hukum yang terkait dengan syirkah.

Syirkah dalam syariah ada dua jenis : syirkah al-amlak dan syirkah al'uqud. Syirkah al-amlak adalah syirkah al-'ayn, yaitu persekutuan dalam pemilikan suatu harta. Misalnya dua orang atau lebih bersekutu atas harta waris, harta yang mereka beli atau harta yang dihgibahkan oleh seseorang kepada mereka bersama, atau semisalnya. ${ }^{15}$ Sedangkan syirkah al-uqud adalah syirkah yang terjadi atas tasharruf. Tasharruf adalah perbuatan atau perkataan yang memiliki akibat hukum (qaulun aw fi'lun lahu atsar hukm). ${ }^{16}$

Syirkah hukumnya ja'iz (mubah), berdasarkan dalil hadits Nabi Shallallahu 'alaihi wa Sallam berupa taqrir (pengakuan) beliau terhadap syirkah. Pada saa beliau diutus sebagai nabi, orang-orang pada saat itu telah bermuamalah dengan cara bersyirkah dan Nabi shallallahu 'alaihi wa Sallam membenarkannya. ${ }^{17}$

Syirkah al-uqud dibagi menjadi lima bentuk : pertama, Syirkah inan, kedua, syirkah abdan, ketiga, syirkah mudharabah, keempat syirkah wujuh dan kelima syirkah mufawadah.

\section{Metodologi Penelitian}

Dalam penelitian ini pendekatan yang digunakan adalah studi pustaka. Studi pustaka adalah penelitian yang dilakukan oleh peneliti dengan mengumpulkan sejumlah buku-buku, majalah, liflet yang berkenaan dengan masalah dan tujuan penelitian. Penelitian yang dilakukan dengan cara menelaah dan membandingkan sumber kepustakaan untuk memperoleh data yang bersifat teoritis. Disamping itu dengan menggunakan studi pustaka peneliti dapat memperoleh informasi tentang teknik-teknik penelitian yang diharapkan, sehingga pekerjaan peneliti tidak merupakan duplikasi.

\section{Hasil Penelitian dan Pembahasan}

Sebagaimana yang di jelaskan pada paragraf sebelumnya tentang badan hukum koperasi dan koperasi dalam tinjauan syariah. Kita sudah bisa menemukan satu

\footnotetext{
15 Yahya Abdurahman. Koperasi Dalam kacamatan Syariah.h.31

${ }^{16}$ Ibid

${ }^{17}$ Ibid
} 
benang merah yang jelas bahwa ketika kita membahas tentang keabsahan badan usaha koperasi menurut syariat Islam maka kita akan mengkaji seputar bagaimana badan usaha koperasi dalam kajian hukum syirkah. Karena badan usaha koperasi merupakan bentuk perseroan atau kerjasama yang dalam Islam dikenal dengan istilah syirkah. Maka sah tidaknya koperasi tergantung apakah ketika pembentukan badan usaha koperasi telah memenuhi unsur-unsur yang harus dalamsyirkah atau sederhananya apakah syarat dan rukun syirkahitu terpenuhi. Jika terpenuhi maka badan hukum nya sah, jika tidak maka badan usaha koperasi batal menurut syariah.

Sebelum kita membahas hal tersebut ada baiknya kita membahas terkait beberapa bagian penting yang terkait dengan hukum syirkah. Agar pemahaman kita tidak keliru dan bisa memahami permasalahan ini dengan baik.

Para ulama ketika membahas masalah-masalah baru yang dihadapi kaum muslimin telah menggariskan kaidah-kaidah tertentu terkait bagaimana cara menetetapkan hukum masalah-masalah tersebut. Hal ini penting dipahami agar kita tidak salah dalam menyimpulkan hukum dari permasalahan kontemporer yang kita akan hukumi. Untuk menarik hukum syariat dari muamalah kontemporer, adalah harus menggunakan 3 langkah. Pertama, memahami fakta (fahmul waqi'), kedua, memahami nash-nash (Fahmun Nushus), ketiga, penarikan hukum (instinbathul hukmi). ${ }^{18}$

\section{a) Memahami Fakta (Fahmul waqi')}

Pemahaman fakta yang akan dihukumi dengan baik dan benar akan menentukan kualitas hukum yang akan dihasilkan nantinya. Hal ini juga berlaku sebaliknya, jika pemahaman terhadap fakta ini salah maka akan berakibat salah juga dalam memahami nash yang akan digunakan untuk menghukumi fakta tersebut yang pada akhirnya akan berakibat pada salahnya menetapkan hukum terhadap permasalahan yang akan duhukumi.

Sebagai contohnya ketika seseorang ustad di tanya tentang hukum beli motor di leasing, apakah dibolehkan dalam syariat Islam atau tidak, tergantung pemahamannya terhadap fakta jual beli motor yang terjadi di leasing tersebut. Jika dia memahami beli motor di leasing itu sebatas jual beli motor biasa maka dia tentu akan menyimpulkan jual beli motor tersebut boleh-boleh saja, karena

18 Dwi Condro Triono, Rekontruksi Bank Syariah dan BMT, h.102 
jual beli memang di bolehkan di dalam Islam. Namun ketika ada yang menyampaikan kepadanya fakta tambahan terkait jual beli tersebut, misalnya jual beli motor di leasing itu di kenakan bunga atau ada ribanya. Maka keputusan hukum yang di berikan berubah menjadi haram.

Dari sini kita bisa melihat terjadi perubahan status hukum beli motor di leasing dari yang dibolehkan menjadi haram, karena ada pemahaman tambahan yang di dapatkan tentang jual beli motor tersebut. Kesimpulannya semakin dalam dan teliti pemahaman kita terhadap fakta yang akan dihukumi maka akan semakin baik dan mendekati kebenaran ketetapan hukum yang dihasilkan. Hal ini juga berlaku sebaliknya.

b) Memahami nash atau dalil (fahmun Nushus)

Setelah kita memahami fakta yang akan kita hukumi secara mendalam, maka langkah selanjutnya adalah memahami nash-nash (fahmun nushus) yang terkait dengan fakta tersebut. Pada tahapan ini kita harus mengumpulkan dan memahami semua nash-nash yang terkait dengan fakta yang akan dihukumi, baik dari Al-Qur'an, hadits, ijma' sahabat maupun qiyas syar'i.

\section{c) Penarikan Hukum (Istibathtul Hukmi)}

Setelah memahami fakta secara mendalam dan memahami nash-nash yang terkait dengan fakta yang akan di hukumi, maka setelah itu kita baru bisa melakukan penarikan hukum (istinbathtul hukmi) terhadap fakta baru (kontemporer tersebut).

Setelah kita memahami terkait dengan cara penarikan hukum (instibathtul hukmi) terhadap fakta yang baru. Maka selanjutnya kita akan membahas tentang hukum syirkah dalam Islam. Kata syirkah dalam bahasa Arab berasal dari kata syarika- yasruku -syarikn wa syirkatan wa syarikatan, artinya menjadi sekutu atau serikat. Kata dasarnya boleh dibaca syirkah, boleh juga dibaca syarikah.Syirkah secara bahasa artinya percampuran dua bagian atau lebih sehingga tidak bisa lagi dibedakan antara yang satu dengan lainnya. ${ }^{19}$ Syirkah hukumnya ja'iz (mubah), berdasarkan dalil hadits Nabi Shallallahu 'alaihi wa

${ }^{19}$ Yahya Abdurahman. Koperasi Dalam Kacamata Syariah.h.31 
Sallam berupa taqrir (pengakuan) beliau terhadap syirkah. Pada saa beliau diutus sebagai nabi, orang-orang pada saat itu telah bermuamalah dengan cara bersyirkah dan Nabi shallallahu 'alaihi wa Sallam membenarkannya. ${ }^{20} \mathrm{Nabi}$ shallallahu 'alaihi wa Sallam bersabda, sebagaimana dituturkan Abu Hurairah radhiyallahu 'anhu :

“Allah 'Azza wa Jalla telah berfirman : Aku adalah pihak ketiga dari dua pihak yang ber-syirkah selama salah satunya tidak mengkhianati yang lainnya. Kalau salah satunya berkhianat, Aku keluar dari keduanya" (HR.Abu Dawud, al-Baihaqi dan Daruquthni)

Sebagaimana semua bentuk akad, maka syirkah itu sehingga sah secara syar'i, harus memenuhi ketentuan syuariah berkaitan dengan rukun dan syarat sah akad. Rukun syirkah ada tiga yaitu : pertama, adanya ijab-qabul (shighat). Kedua, harus ada dua pihak yang berakad (al-aqidani). Ketiga, objek akad (ma'qud 'alayhi). ${ }^{21}$

Dalam hal ijab-qabul, maka di dalamnya harus ada ungkapan baik lisan atau tertulis yang bisa dipahami bahwa salah satu pihak mengajak pihak lain untukberserikat melakukan aktivitas bisnis, dan harus ada penerimaan atau persetujuan pihak lain terhadap ajakan itu. Karena itu sekedar kesepakatan untuk berserikat tidak bisa di sebut akad syirkah. Begitu pula kesepakatan menyerahkan atau menyetor sejumlah harta untuk berserikat juga belum bisa dinilai sebagai akad syirkah. Akan tetapi akad itu harus mengandung pengertian berserikat untuk melakukan suatu aktivitas bisnis. ${ }^{22}$

Kedua pihak yang berakad itu, pihak pertama adalah pihak yang menyatakan ijab yaitu pihak yang menyampaikan ajakan berserikat untuk melakukan suatu aktivitas bisnis. Pihak kedua adalah pihak yang menyatakan qabul atau menerima ajakan itu. Kedua pihak itu syaratnya harus memiliki kelayakan (ahliyah) melakukan tasharruf. Sehingga akad syirkah itu sah, maka disyariatkan pertama, bahwa objek akadnya haruslah berupa tasharruf. Kedua, tasharruf yang diakadkan di dalam akad syirkah itu 
harus bisa diwakalahkan sehingga apa yang diperoleh dari tasharruf itu menjadi hak kedua pihak secara berserikat. ${ }^{23}$

Disamping itu, syirkah di dalam Islam itu di dalamnya harus ada unsur al-badn (unsur badan). Unsur badan ini merupakan unsur mendasar dalam terakadkannya syirkah. Yang dimaksud unsur badan (al-badn) disini bukanlah tubuh atau tenaga, melainkan yang dimaksudkan adalah pribadi yang melakukan tasharruf yaitu pihak yang memiliki hak melakukan tasharruf atau menjalankan aktivitas syirkah. Para fuqaha menggunakan lafazh al-badn agar berposisi sebagai lawan dari harta (modal). Ini adalah istilah fikih dalam bab syirkah. ${ }^{24}$

Keberadaan unsur badan yaitu pribadi yang melakukan tasharruf itu sebagai syarat mendasar di dalam syirkah dikarenakan beberapa alasan : Pertama, karena di dalam syirkah itu harus ada kesepakatan antara dua pihak yang bersyirkah untuk melakukan aktivitas bisnis ('amalun maliyun). Jika hal itu tidak terjadi maka syirkah tidak terakadkan. Kesepakatan kedua pihak untuk melakukan aktivitas bisnis itu mengharuskan bahwa aktivitas itu harus berasal dari kedua pihak atau salah satunya, paling tidak berasal dari salah satu pihak yang berakad. Jika tidak maka artinya tidak terjadi kesepakatan dari keduanya untuk melakukan aktivitas. Karena itu harus ada unsurnya untuk melakukan aktivitas. Karena itu harus ada unsur badan yaitu adanya pribadi yang melakukan tasharruf. ${ }^{25}$

Kedua, syirkah adalah akad atas tasharruf. Tasharrufitu harus keluar dari syarik (pihak yang bersyirkah). Artinya di dalam syirkah itu harus ada mutasharrif (yang melakukan tasharruf) yang padanya berlaku atau terkena akad syirkah. Mka adanya mutasharrif yang terkena akad syirkah merupakan syarat mendasar terakadkannya syirkah. Jika tidak ada mutasharruf maka tidak akan terakadkan syirkah karena adanya penguasaan akad syirkah terhadap mutasharrif. Karena itu syirkah tidak terakadkan jika tidak terjadi atas orang dihijir atau orang gila karena dia tidak layak melakukan tasharruf. Artinya dsitu tidak ada mutasharruf. Ini cukup menjadi argumentasi bahwa akad syirkah tidak terakadkan tanpa adanya mutasharrif yang menjadi sasaran akad

\footnotetext{
${ }^{23}$ Ibid.h.34

${ }^{24}$ Ibid.h.35

${ }^{25}$ Ibid
} 
syirkah itu. Mutasharrif itu maknanya adalah unsur badan. Darisini adanya unsur badan di dalam syirkah merupakan syarat mendasar agar akad syirkah itu terakadkan. ${ }^{26}$

Ketiga, hukum syara' tidak lain berkaitan dengan perbuatan hamba, artinya berkaitan dengan perbuatan pribadi tertentu dan satu pribadi tidak akan diminta pertanggungjawaban atas perbuatan pribadi yang lain. Syirkah adalah hukum syara'. Jadi hukum syirkah itu berkaitan dengan pribadi orang yang bersyirkah. Jika dalam syirkah tidak ada badan yang menjadi sandaran hukum syirkah maka artinya syirkah itu tidak ada dan berikutnya hukum syirkah juga tidak terjadi karena tidaka adanya objek hukumnya. ${ }^{27}$

Para ulama berbeda pendapat tentang bagaimana status hukum koperasi. Sebagian menyatakan koperasi hukumnya boleh. Diantara yang membolehkan koperasi menilai koperasi sebagai syirkah mudharabah. Yaitu kerjasama usaha dimana satu pihak memberikan modal dan pihak lain mengelola syirkah itu.

Mahmut syaltut tidak setuju koperasi (syirkah ta'wuniyah) dianggap sebagai syirkah mudharabah. Sebab di dalam koperasi tidak mengandung unsur mudharabah yang dirumuskan para fuqaha. Sebab syirkah ta'awuniyah, modal usahnya adalah dari sejumlah anggota pemegang saham, dan usaha koperasi itu dikelola oleh pengurus dan karyawan yang dibayar oleh koperasi menurut kedudukan dan fungsinya maisngmasing. Kalau pemegang saham turut mengelola usaha koperasi itu, maka ia berhak mendapatkan gaji sesuai dengan sistem penggajian yang berlaku. Menurut Mahmut syaltut, koperasi adalah syirkah baru yang diciptakan oleh para ahli ekonomi yang dimungkinkan banyak sekali manfaatnya, yaitu memberikan keuntungan kepada anggotanya, ,memberi keuntungan kepada para anggota pemilik saham, membuka lapangan kerja kepada para karyawan., memberi bantuan keuangan dan sebagian hasil koperasi untuk mendirikan tempat ibadah, sekolah dan sebagainya. ${ }^{28}$

Sedangkan Abdurahman Isa menyatakan bahwa syirkah ta'awuniyah (koperasi) adalah syirkah musahamah, artinya syirkah yang dibentuk melalui pembelian sahamsaham oleh para anggotanya. Karena itu syirkah ini adalah syirkah amwal (badan kumpulan modal) bukan syirkah asykhas (badan kumpulan orang), karena di dalam

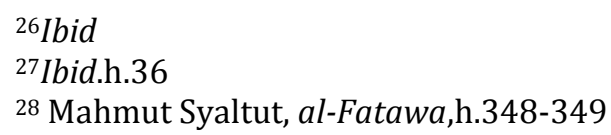


koperasi yang tampak bukan kepribadian para anggota pemilik saham. Menurut Isa, koperasi boleh di dalam Islam dan halal deviden yang diterima para anggota dari hasil usaha koperasi selama koperasi itu tidak mempraktekan usaha-usaha yan mengandung riba dan hal-hal yang diharamkan. ${ }^{29}$

Sebaliknya Dr. Khalid abdurahman Ahmad dalam bukunya at tafkir al-iqtishadi fi al-Islam menilai bahwa koperasi adalah haram dan harta yang diperolah dari koperasi merupakan harta haram. Alasannya, karena prinsip-prinsip keorganisasian koperasi yang tidak memenuhi syarat-syarat yang ditetapkan oleh syariah di antaranya persyaratan anggota yang hanya membatasi satu golongan saja sehingga dianggap ekslusif. Kedua, pembagian keuntungan koeprasi yang dilihat dari segi pembelian atau penjualan dianggap menyimpang dari ajaran Islam, karena menurut bentuk kerjasama dalam Islam (secara klasik) hanya mengenal pembagian keuntungan atas dasar modal, jerih payah atau keduanya. ${ }^{30}$

Ada juga pihak yang berpendapat bahwa untuk menilai koperasi kembali kepada hukum asal muamalah itu sendiri yaitu mubah, selama tidak ada dalil yang mengaharamkannya. Tentu ini adalah pendapat yang tepat, karena mumalah itu terkait dengan perbuatan manusia dan yang lebih tepat bahwa perbuatan manusia itu terikat dengan hukum syara'. Sehingga muamalah yang dihukumi mubah itu adalah selama muamalah itu sesuai dengan rukun dan syarat yang ditetapkan oleh syariat. Karena muamalah memiliki banyak jenis dan bentuk, tidak sedikit juga muamalah yang malah dihukumi haram karena tidak sesuai dengan rukun dan syarat yang di tetapkan syariat. Begitu juga dengan syirkah yang hukumnya adalah boleh selama terpenuhinya rukun dan syarat yang telah di tetapkan syariat, jika menyalahi maka hukumnya haram dan batal atau fasad sehingga meski akadnya dihukumi sah namun tidak bisa di eksekusi selama sebab fasad itu dihilangkan.

Koperasi adalah bentuk syirkah al-uqud. Dalam menentukan status koperasi maka terhadap koperasi itu diterapkan hukum-hukum syariah berkaitan dengan akad syirkah. Jika sesuai dengan hukum-hukum syirkah di dalam Islam maka koperasi itu boleh dan syar'i. Sebaliknya jika koperasi menyalahi ketentuan akad syirkah di dalam Islam maka koperasi itu tidak syar'i. Jika kita telaah akad syirkah koperasi maka akan

\footnotetext{
${ }^{29}$ Abdurahman Isa, Al-mu'amalat al Haditsah wa Ahkamuha,h.65-68

${ }^{30}$ Khalid Abdurahman Ahmad, at tafkir al-iqtishadi fi al-Islam,h.140-142
} 
tampak bahwa koperasi itu syirkah yang batil menyalahi ketentuan Islam tentang syirkah. Hal itu karena :31

Pertama, akad syirkah itu baru sah jika di dalam syirkah itu ada unsur badan, karna akad syirkah merupakan akad antara dua orang atau lebih yang sepakat untuk melakukan aktivitas bisnis untuk tujuan mencari keuntungan. Adanya unsur badan ini harus tampak jelas ketika akad pembentukan syirkah terjadi, yakni adanya pihak yang di beri wewenang untuk mengelola atau melakukan tasharruf terhadap syirkah tersebut. Sehingga ketika akad syirkah terjadi telah jelas mana pihak yang berposisi sebagai mutasharrif (pengelola) mana yang bertindak sebagai pemodal saja. Jika hal ini tidak terpenuhi ketika akad syirkah terjadi, maka syirkah menjadi tidak sah.

Jika kita telaah badan usaha koperasi maka akan tampak bahwa koperasi itu merupakan bentuk syirkah yang terdiri hanya dari harta atau modal saja, tidak ada unsur badan di dalamnya. Artinya ketika akad pembentukan syirkah terjadi, tidak ada yang berposisi sebagai mutasharrif (pengelola) koperasi. Dalam koperasi juga tidak ada kesepakatan untuk melakukan aktivitas bisnis. Namun yang terjadi hanyalah kesepakatan untuk menyetorkan sejumlah harta saja dengan maksud untuk membentuk pengurus. Jadi orang-orang yang ikut andil dalam koperasi yang berserikat hanya harta mereka saja. Hal ini nampak jelas dalam proses pembentukan koperasi. Dalam rapat pembentukan koperasi, rancangan Anggaran Dasar koperasi telah disiapkan oleh panitia yang menyiapkan pendirian koperasi, yang nantinya akad di ajukan dalam rapat yang dihadiri oleh para pendiri. Begitu para pendiri setuju, maka berdirilah koperasi. Selanjutnya para pihak yang diberi kuasa oleh pendiri akan menandatangani Anggaran Dasar Koperasi dan membuat pernyataan akta pendirian koperasi dan disahkan di depan notaris yang juga hadir dalam rapat tersebut. Tampak jelas bahwa syirkah koperasi terbentuk ketika para pendiri setuju untuk bersyirkah dan menyetorkan sejumlah modal tertentu. Tampak jelas pula disana yang terjadi hanya kesepakatan untuk menyetorkan modal saja, bukan untuk menjalankan aktivitas bisnis.

Jadi dalam akad syirkah koperasi itu jelas sekali tidak ada unsur badannya. Sementara unsur badan itu menentukan sah atau tidaknya syirkah yang di bentuk. Dengan demikian secara syar'i koperasi merupakan syirkah yang batil. Karena syirkah

${ }^{31}$ Yahya Abdurahman. Koperasi Dalam kacamata Syariah.h.53 
koperasi adalah batil maka haram bagi seorang muslim untuk mengambilnya, menjalankannya atau terlibat di dalamnya. Konsekuensi berikutnya dari batilnya akad koperasi itu maka harta yang diperolah dari koperasi semacam itu menjadi harta haram, karena di dapatkan dari aktivitas yang tidak sah secara syariat.

Jika dikatakan di dalam koperasi ada pengurus yang menjalankan aktivitas bisnis koperasi atau bertindak sebagai mutasharrif, ini adalah pernyataan yang tidak benar. Karena di dalam hukum syirkah, pengelola (mutasharrif) itu harus sudah ada sejak akad pembentukan atau pendirian syirkah. Artinya pada saat pembentukan syirkah itu sudah harus jelas pihak yang menjadi pengelola dari koperasi tersebut. Hal itu tidak terpenuhi dalam diri pengurus. Karena pengurus koperasi itu tidak ada pada saat pembentukan syirkah atau pendirian koperasi. Pengurus baru ada setelah rapat memilihnya dari kalangan anggota koperasi itu sendiri. Artinya koperasi sudah terbentuk dahulu baru dilakukan rapat anggota untuk memilih pengurus.

Disamping itu, seorang pengelola kontribusi yang diberikan dalam syirkah itu adalah kerja Atau Tasharrufnya. Berdasarkan kontribusinya itulah dia berhak mendapat bagian keuntungan. Jadi akad syirkah itu terjadi atas dirinya. Karena itu ia tidak boleh bekerja melalui suatu perikatan kontrak kerja kepada syirkah yang dikelolanya sendiri itu dan mendapatkan gaji darinya. Sedangkan dalam koperasi, pengurus dimungkinkan mendapatkan gaji rutin perjangka waktu tertentu. Praktek seperti itu jelas menyalahi ketentuan syariat Islam tentang syirkah. Pada saat yang sama pengurus juga mendapat bagian dari SHU dalam kapasitasnya sebagai pengurus. Disamping ia berhak mendapat bagian SHU dalam kapasitasnya sebagai anggota koperasi yang memiliki andil modal. ${ }^{32}$

\section{E. Kesimpulan}

Berdasarkan pembasahan di atas dapat disimpulkan bahwa badan usaha koperasi dan baitul maal wattamwil tidak sesuai dengan syariat Islam karena tidak memenuhi rukun dan syarat terkait dengan pembentukan suatu badan usaha di dalam Islam atau yang lebih di kenal dengan istilah syirkah. Sehingga berdasarkan hal itu badan usaha koperasi tidak sah. Artinya tidak sah pula untuk melakukan aktivitas bisnis. Maka jika koperasi tetap melakukan aktivitas bisnisnya maka hukumnya haram.

${ }^{32}$ Ibid.h. 57 
Munawwaroh, Rahmawati : Koperasi Dan Baitul Maal...

\section{DAFTAR PUSTAKA}

Abdurrahman Isa. Al-mu'amalat al Haditsah wa Ahkamuha. Mesir : Mathba'ah Mukhaimin.tt.

Dwi Utami Nuraini. Badan Usaha dan Koperasi Dalam Perekonomian Indonesia. Yogyakarta : Istana Media.2018

Dwi Condro Triono. Rekonstruksi Bank Syariah dan BMT. Yogyakarta : Daaruts Tsaqofi. 2020.

Khalid Abdurahman Ahmad. at tafkir al-iqtishadi fi al-Islam. Riyadh : Mahtabah al Madinah.1976.cet.2.

Mahmut Syaltut. Al- Fatawa. Kairo : Dar Al Qalam.tt.

Novita Dewi Masyitoh. "Analisis Normatif Undang-Undang No.1 Tahun 2013 Tentang Lembaga Keuangan Mikro (LKM) Atas Status Badan Hukumj dan Pengawasan Baitul Maal Wattamwil (BMT)”Dalam Economica, Volume V, Edisi 2.

Nur.S.Buchori, et.al. Manejemen Koperasi Syariah:Teori dan Praktik. Depok: Rajawali Pers, 2019.

Peraturan Menteri Koperasi dan Usaha Kecil dan Menengah RI N0.11/PER/M/KUKM/XII/2017. Pelaksanaan Kegiatan Usaha Simpan Pinjam dan Pembiayaan Syariah Oleh Koperasi. Jakarta : 2018

Taqiyuddin an-Nabhani. An-Nizham al-Iqtishadi fi al-Islam, terj. Redaksi al-azhar Press, Sistem Ekonomi Islam. Bogor : Al-azhar Press.2009.

UU Republik Indonesia No. 25 Tahun 1992.Perkoperasian. Jakarta : Lembaran Negara RI Tahun 1992, Nomor 116.

Yahya Abdurrahman. Koperasi Dalam Kacamata Syariah. Bogor : Al-Azhar Press. 2011. Cet.2. 